\title{
Recurrent accident and emergency department attendance for acute asthma in children
}

\author{
SUSAN M O'HALLORAN, DAVID P HEAF \\ From the Respiratory Unit, Royal Liverpool Children's Hospital (Alder Hey), Liverpool
}

\begin{abstract}
Asthmatic children aged over 5 years making repeated visits to the accident and emergency department of a children's hospital were compared prospectively, on the basis of a clinicalio questionnaire and pulmonary function tests, with a control group of outpatients with asthma to find the reasons for their repeated attendance. Recurrent attenders $(n=145)$ had more severe asthma than control subjects $(\mathrm{n}=118)$, with greater airway obstruction at rest $\left(\mathrm{FEV}_{1} 79 \% v 84 \% \text { predicted }\right)^{\circ}$ and bronchial lability $(47 \% v 38 \%)$. Significantly more of the "emergency" group used pressurised $\vec{\triangle}$ aerosols and fewer dry powder inhalers to administer bronchodilators. There were no differences inc prophylactic treatment. Seventy one per cent of parents in the emergency group had feared that theirco child would die during an attack, compared with $56 \%$ of control subjects. Eighty one per cent of $\vec{\oplus}$ children were self referred to the accident and emergency department. Most parents had foundo hospital to be the quickest means of obtaining treatment in an emergency. There were no differences between the two groups in parents' knowledge about asthma, home conditions, or social disadvantage. Although children who repeatedly attend hospital accident and emergency depart- $\frac{\supset}{0}$ ments for treatment of acute attacks have more severe asthma than controls and show some⿳亠丷厂巾 deficiencies in treatment, the major determinant of attendance appeared to be the parents' conviction $\frac{\AA}{\AA}$ that appropriate treatment could not be obtained elsewhere.
\end{abstract}

\section{Introduction}

Asthma is the most common chronic illness of childhood, affecting about $10 \%$ of schoolchildren. ${ }^{1}$ There has been a substantial increase in the number of hospital admissions for asthma in children in recent years, ${ }^{23}$ and no reduction in deaths. ${ }^{4}$ Studies of deaths from asthma in adults and children have shown failure to appreciate the severity of the attack and delay in initiating effective treatment-by patients, their families, and doctors in general practice and hospital. Many deaths from asthma are potentially avoidable..$^{5-7}$ Direct, patient initiated admission to hospital has been shown to be of value in adults with severe asthma ${ }^{8}$ and studies in children have shown an increase in the number of asthmatic children self referred to hospital by parents, bypassing the general practitioner. ${ }^{29}$ Emergency attendance at hospital provides prompt initial relief of symptoms, but may not be the most appropriate response to acute attacks in children.

Address for reprint requests: Dr S M O'Halloran, Respiratory Unit, Royal Liverpool Children's Hospital (Alder Hey), Liverpool L12 2AP.

Accepted 9 June 1989
Hospital attendance and admission are undesirable in children unless there is no alternative. Experience in the management of asthma cannot be guaranteed in an $\overrightarrow{\overrightarrow{0}}$ accident and emergency department, ${ }^{10}$ and facilities for long term follow up are unlikely to be available.

To investigate the reasons why emergency hospital 3 attendance for acute asthma is increasing in children, we have studied a group of asthmatic children making repeated visits to the accident and emergency depart- 0 ment of a children's hospital during an acute attack during one year. They have been compared with $a \frac{D}{O}$ group of asthmatic children attending hospital outpatients who have not required recent treatment in the $\widetilde{N}$ accident and emergency department.

\section{Patients and methods}

The Royal Liverpool Children's Hospital (Alder Hey) is the largest children's hospital in the United $\mathscr{D}$ Kingdom. The accident and emergency department serves a population of about 150000 children aged under 16 years.

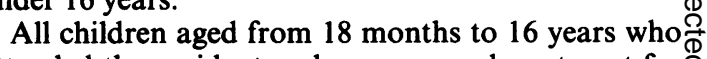
attended the accident and emergency department for $\cong$ treatment of acute asthma between 1 January and $31 \%$ 
December 1986 and who had also attended at least once during the preceding 12 months were eligible for the study (emergency group). Children less than 18 months old were excluded because of the difficulty of establishing a firm diagnosis of asthma in this age group. Because of the small number of children under 5 in the control group and the absence of pulmonary function data in the younger children this report is confined to children aged 5 and over.

We also recruited a control group of asthmatic children attending the hospital as outpatients who had not required emergency hospital treatment for at least a year. Control children were attending the hospital regularly at the clinics of eight consultant paediatricians, one of whom is a paediatric respiratory physician. They were recruited either on attendance at the respiratory function laboratory for routine pulmonary function tests or in response to a letter asking for volunteers distributed in the outpatient clinic.

Children were assessed on the basis of answers to questionnaires, weight and height, results of pulmonary function tests, assessments of inhaler technique, and theophylline concentrations (where appropriate). If the children were admitted interviews were carried out while they were in the ward. If they were not admitted their parents were contacted and asked to bring them to the hospital three to four weeks later. This interval was selected to allow reasonable time for return of lung function to normal yet to avoid excessive delay so that details of the attack were not forgotten. Parents were asked to bring all the treatment the child was having when they attended.

All treatment was omitted on the day of the pulmonary function tests. Airway obstruction at rest was assessed by peak expiratory flow (PEF), measured by a Wright's peak flow meter, and a computerised flow-volume loop (Micro Medical Industries) with measurement of forced expired volume in the first second $\left(\mathrm{FEV}_{1}\right)$, forced vital capacity, maximum mid expiratory flow between $25 \%$ and $75 \%$ of vital capacity, and forced expired flow at $50 \%$ and $25 \%$ of vital capacity. This was followed by a six to eight minute free running exercise challenge, ${ }^{\text {" with }}$ encouragement to maintain a heart rate of $170-190$ beats per minute. Peak expiratory flow was measured three and five minutes from the start of exercise and three, nine, and 15 minutes afterwards. The child then took his or her usual bronchodilator, inhaler technique was observed, and PEF was measured after two, five, and 10 minutes. The inhaler technique was compared with the manufacturer's instructions and graded as good, fair, or poor. The exercise test was not carried out if the resting PEF was less than $60 \%$ of the value predicted for height.

After the year's study had been completed, a postal questionnaire was sent to all parents who had taken part to ask whether they had needed to see their general practitioner as an emergency because of the child's asthma during the study year. Questionnaire replies and pulmonary function test results were compared to find differences in the severity of asthma and its treatment; home environment and socioeconomic conditions; parents' knowledge, perceptions, and fears; and general practitioners' attendance. Informed consent was obtained from parents for the pulmonary function tests to be performed and copies of all results were sent to the consultant treating the child. Ethical committee approval was obtained before the study was started.

Statistical analysis used the $\chi^{2}$ test, Student's $t$ test, and the Mann-Whitney $U$ test (with the Statistics Program for the Social Sciences).

\section{Results}

During 1986820 children (median age $5 \cdot 5$, range $1 \cdot 5$ 16 years) made 1389 visits to the accident and emergency department of the Royal Liverpool Children's Hospital (Alder Hey) for emergency treatment of acute asthma. Of these, 323 children made two or more visits (total 835 , median $4 \cdot 5$, range $2-16$ visits) in 12 months and were eligible for inclusion in the study. Questionnaire data were obtained from 301 children $(93 \%)$, of whom 145 were over the age of 5 years. A control group was recruited from outpatients clinics, of whom 118 were aged over 5 years.

The emergency group of 145 children had a mean age of 9.46 years; $75 \%$ were boys. The control group of 118 children had a mean age of 10.08 years; $70 \%$ were boys. There was no significant difference in age, sex, weight, or height between the two groups. Eighty six children $(61.4 \%)$ in the emergency group were also attending an outpatient clinic at the hospital.

Table 1 Severity of the usual and worst ever attacks in the emergency and control groups

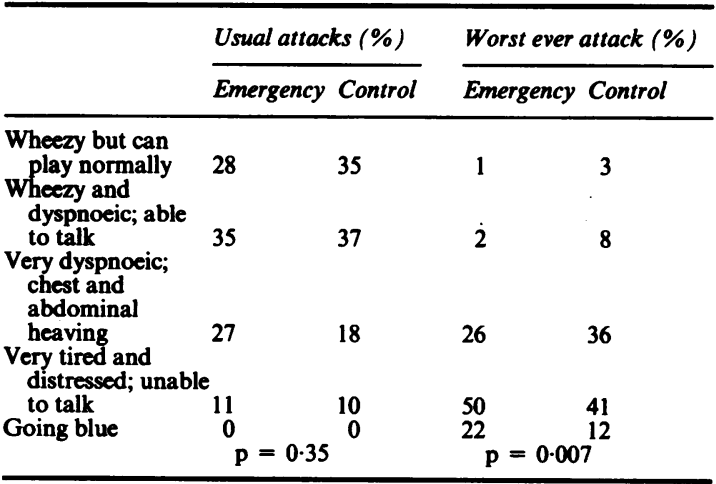


Table 2 Results of pulmonary function tests (mean (SD) values)* in the emergency and control groups

\begin{tabular}{|c|c|c|c|c|}
\hline & Emergency group & Control group & $p$ & 읃 \\
\hline $\begin{array}{l}\mathrm{FEV}_{1}(\% \text { pred }) \\
\text { Exercise induced bronchoconstriction: \% fall in FEV }\end{array}$ & 79 (19) & 84 (18) & 0.02 & \\
\hline $\begin{array}{l}\text { Exercise induced bronchoconstriction: } \% \text { fall in } \mathrm{FEV}_{1} \\
\text { (normal }<15 \%)\end{array}$ & 39 (19) & $33 \quad(21)$ & 0.02 & D. \\
\hline $\begin{array}{l}\text { Bronchodilator response: \% increase in FEV } \\
(\text { normal }<15 \%) \\
\text { Lability index }(\text { normal }<20 \%)\end{array}$ & $\begin{array}{ll}31 & (16) \\
47 & (20)\end{array}$ & $\begin{array}{ll}26 & (16) \\
38 & (24)\end{array}$ & $\begin{array}{l}0.006 \\
0.01\end{array}$ & D \\
\hline
\end{tabular}

*More detail on pulmonary function is available from the authors on request.

\section{SEVERITY OF ASTHMA}

Children in the emergency group had significantly more severe asthma. They developed the disease younger (mean age 3.2 years, controls 4.2 years; $\mathrm{p}=<0.05)$ and had a history of more severe "worst ever" attacks, though there was no difference in current attacks (table 1). They had more absences from school than controls (figure). Pulmonary function tests showed the emergency group children to have greater airway obstruction at rest, exercise induced bronchoconstriction, and bronchodiltor responsiveness (table 2 ).

\section{TREATMENT}

The only difference in treatment that emerged was that emergency group children were significantly more likely to use a pressurised aerosol and less likely to use a dry powder inhaler to take their bronchodilator (table 3). Most families (97\% of emergency group, $99 \%$ of controls) had some form of treatment in the home, and $68 \%$ and $85 \%$ respectively would treat the

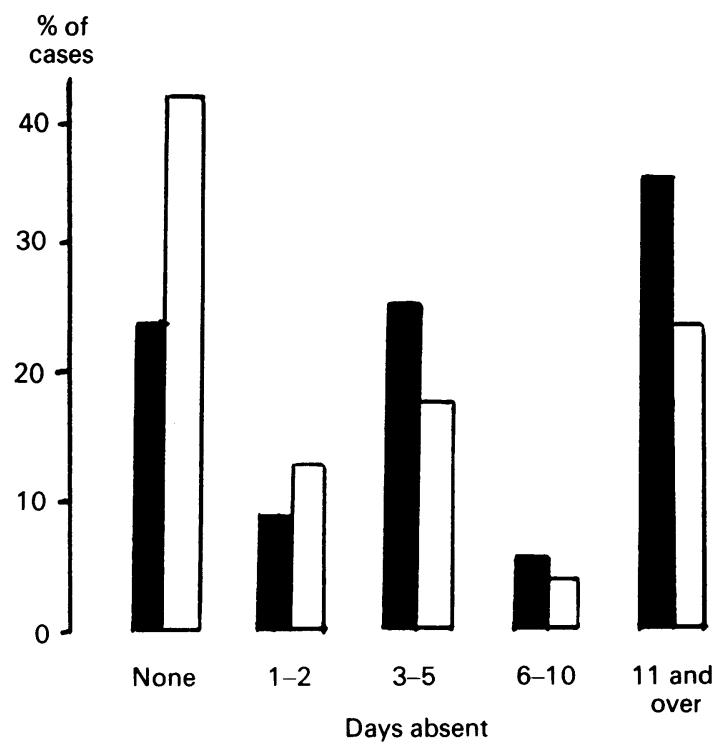

Absence from school due to asthma in the last term in the emergency group ( $\square$ ) and the control group ( $\square$ ). child as soon as he became wheezy (no significan $\stackrel{\circ}{\bullet}$ difference). Most children ( $86 \%$ of emergency group $85 \%$ of controls) were able to take their inhalers tos school; the remainder were prohibited by theipo schools. Inhaler technique was considered adequat心 in $83 \%$ of emergency group children and $81 \%$ of controls. Although all the children were aged at least $\rho$ years, some used only oral treatment (table 3 ). $\mathrm{NQ}$ child in either group had a supply of oral corticosteroids at home to take for a severe attack.

There were no differences between the groups in prophylactic treatment. Twenty eight per cent of emergency group children and $32 \%$ of controls tooke no regular treatment and some took only brong chodilators. There was no difference in the type of prophylactic drug used by the two groups (table 3). No children performed peak flow measurements at home

HOME AND SOCIAL CONDITIONS

There were no differences between the groups in potentially adverse conditions in the home. Sixty fous per cent of emergency group families and $59 \%$ oft controls had a parent who smoked and keeping pets was common- $54 \%$ and $61 \%$ respectively, mos commonly a dog. Parents often carried out extre cleaning to reduce dust in the house $(73 \%$ of emerigency group, $72 \%$ of controls). The number of fathers. who were unemployed ( $23 \%$ in emergency group, $26 \%$ in control families) was similar to the male un₹ employment rate for Liverpool at the time of the studyo (25.8\%, Department of Health and Social Security March 1986). There was no difference in the sociat class distribution for either parent by current or pas $\overrightarrow{\vec{F}}$ occupation. Emergency group families had less easye access to transport in a crisis, $28 \%$ having neither a caf of their own nor a lift, compared with $16 \%$ of controlv children $(p<0.02)$.

PARENTS' KNOWLEDGE ABOUT ASTHMA

Parents in the two groups were equally well informed about asthma; $56 \%$ of both groups made an accurateo assessment of the prevalence of asthma, $83 \%$ and $72 \%$ respectively knew the lungs were the organ affected and $81 \%$ and $87 \%$ that the major change during ari attack was narrowing of small airways, and $87 \%$ anf $75 \%$ thought that children could grow out of asthma< 
Table 3 Treatment in the emergency and control groups

\begin{tabular}{|c|c|c|c|c|c|}
\hline & \multicolumn{2}{|c|}{$\begin{array}{l}\text { Emergency } \\
(n=145)\end{array}$} & \multicolumn{2}{|c|}{$\begin{array}{l}\begin{array}{l}\text { Control } \\
(n=118)\end{array} \\
\end{array}$} & \multirow[b]{2}{*}{$p$} \\
\hline & No & $(\%)$ & No & $(\%)$ & \\
\hline $\begin{array}{l}\text { ACUTE } \\
\text { Oral bronchodilator } \\
\text { Inhaled bronchodilator } \\
\text { Pressurised aerosol } \\
\text { Tube spacer } \\
\text { Large volume spacer } \\
\text { Dry powder inhaler } \\
\text { Nebulised bronchodilator }\end{array}$ & $\begin{array}{r}23 / 145 \\
121 / 145 \\
50 / 121 \\
4 / 121 \\
21 / 121 \\
46 / 121 \\
11 / 121\end{array}$ & $\begin{array}{r}(16) \\
(83) \\
(41) \\
(3) \\
(18) \\
(38) \\
(8)\end{array}$ & $\begin{array}{l}21 / 118 \\
96 / 118 \\
26 / 96 \\
10 / 96 \\
8 / 96 \\
52 / 96 \\
7 / 11\end{array}$ & $\left.\begin{array}{l}(18) \\
(81) \\
(28) \\
(10) \\
(7) \\
(54) \\
(6)\end{array}\right\}$ & $\begin{array}{l}\text { NS } \\
\text { NS } \\
<0.01 \\
\text { NS }\end{array}$ \\
\hline $\begin{array}{l}\text { PROPHYLAXIS } \\
\text { Oral bronchodilator } \\
\text { Inhaled bronchodilator } \\
\text { Nebulised bronchodilator }\end{array}$ & $\begin{array}{r}3 / 145 \\
10 / 145 \\
1 / 145\end{array}$ & $\begin{array}{l}\text { (3) } \\
\text { (7) } \\
\text { (1) }\end{array}$ & $\begin{array}{l}2 / 118 \\
7 / 118 \\
0\end{array}$ & $\begin{array}{l}\text { (2) } \\
(6)\end{array}$ & $\begin{array}{l}\text { NS } \\
\text { NS }\end{array}$ \\
\hline $\begin{array}{l}\text { Sodium cromoglycate } \\
\text { Spinhaler } \\
\text { Pressurised aerosol } \\
\text { Large volume spacer } \\
\text { Nebuliser }\end{array}$ & $\begin{array}{l}55 / 145 \\
28 / 55 \\
16 / 55 \\
8 / 55 \\
3 / 55\end{array}$ & $\begin{array}{l}(38) \\
(52) \\
(28) \\
(15) \\
(5)\end{array}$ & $\begin{array}{l}43 / 118 \\
26 / 43 \\
15 / 43 \\
2 / 43 \\
0\end{array}$ & $\left.\begin{array}{r}(36) \\
(60) \\
(35) \\
(5)\end{array}\right\}$ & $\begin{array}{l}\text { NS } \\
\text { NS }\end{array}$ \\
\hline $\begin{array}{l}\text { Inhaled steroids } \\
\text { Pressurised aerosol } \\
\text { Tube spacer } \\
\text { Large volume spacer } \\
\text { Dry powder inhaler } \\
\text { Nebuliser }\end{array}$ & $\begin{array}{c}41 / 145 \\
12 / 41 \\
9 / 41 \\
5 / 41 \\
11 / 41 \\
5 / 41\end{array}$ & $\begin{array}{l}(28) \\
(28) \\
(23) \\
(11) \\
(26) \\
(12)\end{array}$ & $\begin{array}{c}27 / 118 \\
2 / 27 \\
5 / 27 \\
7 / 27 \\
11 / 27 \\
2 / 27\end{array}$ & $\left.\begin{array}{c}(36) \\
(8) \\
(19) \\
(27) \\
(38) \\
(8)\end{array}\right\}$ & $\begin{array}{l}\text { NS } \\
\text { NS } \\
\text { NS }\end{array}$ \\
\hline Oral steroids & 0 & & 0 & & \\
\hline Theophyllines & $38 / 145$ & (26) & $20 / 118$ & (17) & NS \\
\hline Good inhaler technique & $103 / 145$ & (84) & $87 / 118$ & (81) & NS \\
\hline Mean (SD) serum theophylline concentration $(\mu \mathrm{g} / \mathrm{ml})$ & $8(7)$ & & $10(6)$ & & NS \\
\hline
\end{tabular}

Fewer emergency group parents thought that it was possible to reduce the frequency of attacks $(54 \%$ compared with $75 \% ; p<0.01$ ).

\section{PARENTS' CONCERNS ABOUT ASTHMA}

Parents were asked if they thought that it was theoretically possible for children to die from asthma. Similar numbers thought that it was $(72 \%, 70 \%)$. Many more parents in the emergency group, however, had been afraid at some time that their own child would die $-71 \%$ compared with $56 \%$ of controls (p < 0.02). Emergency group parents would also seek help at an earlier stage in an attack: $61 \%$ would look for help when the child was wheezy with his chest heaving but still able to talk, compared with $41 \%$ of control parents $(p<0.01)$.

\section{ACCIDENT AND EMERGENCY DEPARTMENT ATTENDANCE DURING ATTACKS}

On their most recent visit to the accident and emergency department 118 of the 145 children $(81 \%)$ were self referred, compared with $43(32 \%)$ on their first visit. The change in referral was significant (table 4). When asked where they would look for medical assistance if the child had a severe attack, 124 parents said the hospital, 13 their general practitioner, and eight either. The reasons for their choice are shown in table 5.

Despite their preference for hospital care during acute attacks, the follow up questionnaire, returned by 92 emergency group parents and 62 controls, shows that recurrent hospital attenders are still users of primary care. During the study year 31 emergency group children (34\% of those replying) and 29 controls $(47 \%)$ had seen their general practitioner for acute asthma (difference not significant). Emergency group children had visited the general practitioner more frequently (mean 4.0 visits) than the outpatient department $(2.4$ visits; $p<0.02)$.

\section{Discussion}

The results of the study show that asthmatic children who repeatedly attended the accident and emergency

Table 4 Details of referral for first and last visit to accident and emergency department

\begin{tabular}{|c|c|c|c|c|}
\hline \multirow[b]{2}{*}{ Person referring } & \multicolumn{2}{|c|}{ First visit } & \multicolumn{2}{|c|}{ Last visit } \\
\hline & No & $(\%)$ & No & $(\%)$ \\
\hline $\begin{array}{l}\text { Parents } \\
\text { GP } \\
\text { Locum } \\
\text { GP over telephone } \\
\text { Other (eg teacher) } \\
\text { Can't remember }\end{array}$ & $\begin{array}{r}43 \\
51 \\
27 \\
7 \\
1 \\
4\end{array}$ & $\begin{array}{l}(32) \\
(35) \\
(19) \\
(5) \\
(0 \cdot 7) \\
(3)\end{array}$ & $\begin{array}{r}118 \\
11 \\
4 \\
5 \\
0 \\
0\end{array}$ & $\begin{array}{r}(81) \\
(8) \\
(3) \\
(4)\end{array}$ \\
\hline $\begin{array}{l}\text { Child deteriorated therefore } \\
\text { did not wait }\end{array}$ & 8 & (6) & 5 & (3) \\
\hline
\end{tabular}

Difference between first and last visit: $\mathrm{p}=<0.001$. 
Table 5 Reasons for choosing hospital accident and emergency department ( $A E D$ ) or general practitioner*

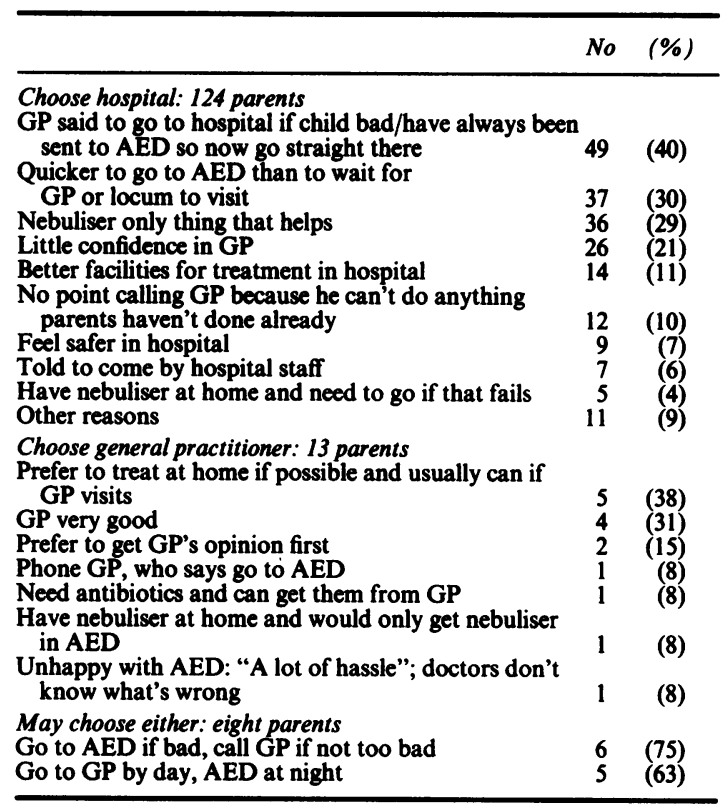

*Many parents had more than one reason for their choice.

department of a children's hospital for treatment of acute attacks had more severe asthma than control subjects. They were more likely to use pressurised inhalers to deliver bronchodilators, though they received similar prophylactic treatment. Between the first and the last visit many parents had begun to go directly to hospital without the intervention of their general practitioner. Their reasons for attending hospital suggest that they had learned that it was the quickest way to obtain treatment. More emergency group parents than controls had feared at some time that their child would die during an attack and they sought medical treatment at an earlier stage.

Assessment of the severity of asthma in our two groups of children suggests that emergency group children have more severe disease, though both groups come from the more severe end of the range of asthma. Their pulmonary function test results are similar to the more severely affected Melbourne children studied by Hill. ${ }^{12}$ Comparison with the London children reported in a community survey by Anderson ${ }^{13}$ shows that only $12 \%$ of his children missed more than 31 days' school in a complete year; $35 \%$ of our emergency group children had missed the equivalent, more than 10 days in a single term.

Undertreatment of asthma is known to be common. ${ }^{514}$ Our emergency group had more severe asthma than the controls but the only significant difference in treatment was that they used pressurised aerosols more and dry powder inhalers less than controls. Many asthmatic children and adults experience difficulty in using pressurised aerosols correctly an dry powder devices have been shown to be a more effective means of delivering bronchodilators i children. ${ }^{15}$ Use of better inhalers might enable attack $\overline{\text { D }}$ to be treated more effectively by the child and his of her family. Although all the children in both ouf groups were over 5 years of age and should have beer $\vec{P}$ able to use some type of inhaler, some received only oral bronchodilators. No families had oral cortico steroids available for an acute attack.

There was no difference between the two groups in the amount or type of prophylactic treatment. Twents eight per cent of the emergency group and $32 \%$ of controls took no regular treatment and some usedy bronchodilators only. There was no difference in the type of inhaler used. Theophyllines were commonly used but $75 \%$ of the emergency group and $50 \%$ of control children had subtherapeutic serum concentrac tions.

Both our groups were receiving relatively intensive treatment compared with asthmatic children iroo community studies. Only $21 \%$ of the children of Anderson $e t$ al had used a bronchodilator and 16\% some form of prophylaxis during three months. ${ }^{12}$ Stor et $a l^{16}$ found that $4.9 \%$ of primary school children iob Sussex used inhaled treatment, of whom $22 \%$ too 20 sodium cromoglycate, and $16 \%$ inhaled cortico $\mathbb{D}$ steroids, $2 \%$ having a home nebuliser; $2 \%$ took oraf theophylline. Although the only difference between our groups was in the type of inhaler used fop bronchodilators, several deficiencies in the treatment? of both groups is nevertheless apparent.

Social class and environmental conditions in the home did not affect emergency attendance, though adverse social conditions have been associated witks suboptimal treatment ${ }^{17}$ and a greater risk of deatip. from asthma. ${ }^{18}$ Evans et al reported an excess of families who smoked among hospital attenders for acute asthma. ${ }^{19}$ Parental smoking was common in both our groups, but no more so in emergency group families.

Parents in both our groups showed good basia knowledge about asthma, and most were confiden $P$ that they could judge when medical help was needed during an attack. Conway and Littlewood found that parents' assessment of severity corresponded well witto that of the admitting doctor. ${ }^{20}$

Most parents in both groups were aware tha震 asthma could be fatal. A far greater proportion of emergency group parents had feared at some time thato their own child was about to die than had our controls or the $50 \%$ of Melbourne families reported b\$ Reddihough et al. ${ }^{21}$ The study by Evans et al og emergency room attendance by asthmatic children is 
New York ${ }^{19}$ showed that parents' fear that the child might die during the current attack was not associated with an increased number of visits, but they did not inquire about previous attacks. Our emergency group children had similar current attacks to those of controls, but a history of more severe "worst ever" attacks. In a case-control study of asthma deaths in New Zealand, Rea et $a l^{22}$ have shown that those who died were more likely than community controls to have needed emergency room treatment or admission in the previous year and more likely than hospital and community controls to have had a life threatening attack in the past. Our group of recurrent hospital attenders can therefore be considered to be a high risk group and the parents' fears cannot be discounted.

Frequent attacks due to inadequate prophylaxis and greater parental anxiety as a result of severe attacks in the past do not alone explain why children attend accident and emergency departments repeatedly during acute attacks. There was a substantial change from general practitioner referral to self referral between the first and most recent visit by our emergency group children. Anderson et $a l^{9}$ reported a fivefold increase in self referrals to London hospitals from 1970 to 1978 , by which time $44 \%$ of children admitted were self referred. Many of the parents in our emergency group had been told by their general practitioner to go to hospital if the child had a bad attack or had found his treatment inadequate or the wait for a visit unacceptably long. Some children had a home nebuliser but only $2 \%$ had received nebulised treatment from their general practitioner, though nebulisers can be used successfully in general practice..$^{23} \mathrm{~A}$ study of the use of nebulisers in general practice in Liverpool ${ }^{24}$ shows that only $32 \%$ of practices sampled had a nebuliser and that the deputising service, which was used by $91 \%$ of practices, did not use nebulisers at all. Some parents in our study stated that they came to hospital to get treatment by nebuliser. Possibly the desire to obtain nebuliser treatment for their children, combined with awareness that this is unlikely to be available outside hospital, is one of the factors that contributes to accident and emergency department attendance.

In conclusion, our group of children who repeatedly come to the accident and emergency department during acute attacks of asthma were from a severely affected group who have a history of frightening attacks. They were more likely to take their bronchodilators by pressurised aerosol and may thus have obtained less good relief than the control children. Their parents were well informed about asthma and had feared at some time that the child would die during an attack. They sought help earlier than controls and many had learned from experience to go to hospital when treatment at home had failed. Better long term management of asthmatic children, including careful choice of a suitable inhaler, should reduce the number of attacks and enable a greater proportion to be treated successfully by parents. When treatment at home fails, prompt, effective treatment by the general practitioner, which commands the confidence of parents, could reduce the need for emergency hospital treatment. Without such changes it is likely that the steep increase in hospital attendances will continue.

We thank Dr David Downham and Dr Jane Hutton for statistical advice and Mr Chris West for carrying out the computer analysis of data.

\section{References}

1 Lee DA, Winslow NR, Speight ANP, Hey EN. Prevalence and spectrum of asthma in childhood. Br Med J 1983;286:1258-60.

2 Anderson HR. Increase in hospitalisation for childhood asthma. Arch Dis Child 1978;53:295-300.

3 Mitchell EA. International trends in hospital admission rates for asthma. Arch Dis Child 1985;60:376-8.

4 Burney PGJ. Asthma mortality in England and Wales: evidence for a further increase 1974-84. Lancet 1986;ii:323-6.

5 Fletcher HJ, Ibrahim SA, Speight ANP. Survey of childhood asthma deaths in the Northern Region 1970-1985. Proceedings of the British Paediatric Association annual scientific meeting, 1987 (abstract).

6 British Thoracic Association. Deaths from asthma in two regions of England. Br Med J 1982;285:1251-5.

7 Carswell F. Thirty deaths from asthma. Arch Dis Child 1985;60:25-8.

8 Crompton GK, Grant IWB. Edinburgh Emergency Asthma Service. Br Med J 1975; iv:680-2.

9 Anderson HR, Bailey P, West S. Trends in the hospital care of acute childhood asthma 1970-78: a regional study. Br Med J 1980;281:1191-4.

10 Reed S, Diggle S, Cushley MJ, Sleet RA, Tattersfield AE. Assessment and management of asthma in an accident and emergency department. Thorax 1985;40:897-902.

11 Jones RS. Assessment of respiratory function in the asthmatic child. $\mathrm{Br}$ Med J 1966;ii:972-5.

12 Hill DJ, Landau LI, McNicol KN, Phelan PD. Asthmathe physiological and clinical spectrum in childhood. Arch Dis Child 1972;47:874-81.

13 Anderson HR, Bailey PA, Cooper JS, Palmer JC, West S. Morbidity and school absence caused by asthma and wheezing illness. Arch Dis Child 1983;58:777-84.

14 Speight ANP, Lee DA, Hey EN. Underdiagnosis and undertreatment of asthma in childhood. Br Med J 1983;286: 1253-6.

15 Chambers S, Dunbar J, Taylor B. Inhaled powder compared with aerosol administration of fenoterol in asthmatic children. Arch Dis Child 1980;55:73-4.

16 Storr J, Barrell E, Lenney W. Asthma in primary schools. Br Med J 1987;295:251-2.

17 Anderson HR, Cooper JS, Bailey PA, Palmer JC. Influence of illness label and social, family and health 
service factors on drug treatment of childhood asthma. Lancet 1981;ii:1030-2.

18 Sears MR, Rea HH, Fenwick J, et al. Deaths from asthma in New Zealand. Arch Dis Child 1986;61:6-10.

19 Evans D, Levison MJ, Feldham CH, et al. The impact of passive smoking on emergency room visits of urban children with asthma. Am Rev Respir Dis 1987; 135:567-72.

20 Conway SP, Littlewood JM. Admission to hospital with asthma. Arch Dis Child 1985;60:636-9.

21 Reddihough DS, Landau LI, Jones HJ, Richards WS.
Family anxieties in childhood asthma. Austr Paediatr $J$ 1977;13:295-8.

22 Rea HH, Scragg R, Jackson R, Beaglehole R, Fenwick J, Sutherland DC. A case-control study of deaths from asthma. Thorax 1986;41:833-9.

23 Barritt PW, Hodgson KG. Use of the nebuliser in home asthmatic care. General Practice Update 1985;30: 1027-32.

24 O'Halloran SM, Heaf DP. Availability of nebuliser treatment for childhood asthma in general practice. Paediatr Rev Commun 1989;3:155-60. 